\title{
Differential response in chick survival to diet in least and crested auklets
}

\author{
Adrian E. Gall ${ }^{1,3, *}$, Daniel D. Roby ${ }^{1}$, David B. Irons ${ }^{2}$, Ian C. Rose $^{1}$ \\ ${ }^{1}$ USGS-Oregon Cooperative Fish and Wildlife Research Unit and Department of Fisheries and Wildlife, \\ Oregon State University, Corvallis, Oregon 97331, USA \\ ${ }^{2}$ Migratory Bird Management, US Fish and Wildlife Service, 1011 E. Tudor Rd, Anchorage, Alaska 99503, USA \\ ${ }^{3}$ Present address: ABR Inc. - Environmental Research \& Services, PO Box 80410, Fairbanks, Alaska 99708, USA
}

\begin{abstract}
Least auklets Aethia pusilla and crested auklets A. cristatella are abundant planktivorous seabirds found throughout the Bering Sea and are inextricably linked to the secondary productivity of this northern marine ecosystem. We assessed the relationship between productivity and diet in least and crested auklets by examining breeding chronology, daily survival rates (DSR) of chicks, and nestling diet composition at 2 mixed colonies on St. Lawrence Island in the northern Bering Sea during the 2000 to 2002 breeding seasons. Nestlings of both least and crested auklets hatched earlier, had higher survival rates, and were fed more of the large, oceanic copepod Neocalanus cristatus in 2002 compared to the $2 \mathrm{yr}$ of lower chick survival. In contrast, during the year of lowest DSR for both auklet species (2001), the small copepod Calanus marshallae was more prevalent in the diet of least auklets and the mid-sized copepod $N$. flemingeri was more prevalent in the diet of crested auklets compared to the other $2 \mathrm{yr}$. The prevalence of oceanic copepods in meals fed to chicks explained much of the annual variation in DSR in least auklets. Interannual differences in timing of nest initiation, nest survival, and diet of least and crested auklets may be associated with the strength of the cold, nutrient-rich Anadyr Current, which passes in close proximity to St. Lawrence Island and has important influences on zooplankton productivity and distribution. Auklet productivity and diet composition may serve as key indicators in the overall effort to monitor the impact of climate change on the productivity of the Bering Sea.
\end{abstract}

KEY WORDS: Auklets · Bering Sea $\cdot$ Chick survival · Anadyr current · Aethia spp. $\cdot$ Neocalanus spp. Climate change

Resale or republication not permitted without written consent of the publisher

\section{INTRODUCTION}

Predicting responses of marine ecosystems to climate change and measuring the appropriate parameters to detect these potential responses require understanding the mechanisms by which climate and oceanography affect biological processes (Hunt et al. 2002). Remote sensing techniques have been used to measure changes in climatic and oceanographic conditions (Miller \& Schneider 2000), but these methods do not measure responses of upper-trophic-level organisms. Trophic webs in the Bering Sea and northern Gulf of Alaska recently have shown evidence of a transition to the negative phase of the Pacific Decadal Oscillation similar in magnitude to the positive phase shift that occurred in the late 1970s (Hare \& Mantua 2000, Miller \& Schneider 2000, Macklin et al. 2002). This shift is characterized by a horseshoe-shaped pattern of warm sea-surface temperatures in the northern, western, and southern Pacific, associated with a warming trend in the Bering Sea region (Niebauer 1998, Hare \& Mantua 2000). Additionally, the weight of scientific data and traditional ecological knowledge indicate that global warming may be profoundly affecting the physical and biological characteristics of the Bering Sea (ACIA 2004). Such large-scale changes in oceanographic conditions will likely have major effects on secondary productivity, particularly on dominant grazing zooplankton (i.e. calanoid copepods, euphausiids). These invertebrates are the primary prey of a variety of 
planktivores, including least and crested auklets (Aethia pusilla and A. cristatella), 2 species of seabirds that number in the millions at nesting colonies throughout the Bering Sea.

Data on physical oceanography, zooplankton abundance and distribution, forage fish stocks, and seabird foraging ecology in the Bering Sea may be obtained during research cruises (Piatt et al. 1990, Hunt et al. 1998), but the high cost of at-sea sampling severely limits the frequency and coverage of these cruises. Alternatively, monitoring nesting seabirds is far less expensive than ship-based monitoring programs and can be used to explore the relationship between avian predators and their marine food supply on a regional scale (Cairns 1987). Reproductive success, diet composition, and adult survival of seabirds may serve as useful indicators of variation in prey availability, as well as changes in large-scale oceanographic conditions (Hatch \& Hatch 1988, Bertram et al. 2000, Hedd et al. 2002, Jones et al. 2002).

St. Lawrence Island, located in the northern Bering Sea, is the nesting area for more than $10 \%$ of Alaska's estimated 36 million breeding seabirds (Stephensen et al. 1998). These populations are sustained by abundant zooplankton and forage fish in the highly productive waters of the northward-flowing Anadyr Current, which advects nutrient-rich oceanic water into the region west and north of the island (Hansell et al. 1989, Pavlov \& Pavlov 1996, Piatt \& Springer 2003). Least and crested auklets are the most abundant planktivorous seabirds nesting on St. Lawrence Island, as well as on other islands throughout the Bering Sea (Jones 1993a,b). These auklets nest primarily in talus slopes, where they lay a single egg in a natural crevice beneath the talus surface. Both species exhibit biparental care, with incubation and chick-rearing duties shared by both sexes.

The auklet colonies on St. Lawrence Island are among the largest in Alaska (Jones 1993a, b, Stephensen \& Irons 2003); about 4 million auklets nest in several mixed colonies along the northern and western coasts of the island, with least auklets outnumbering crested auklets by about 2:1 (V. Zubakin pers. comm.). Despite the enormous size of these colonies and their key role in the food web of the northern Bering Sea (Springer \& Roseneau 1985), no recent, multiyear studies of breeding biology or foraging ecology of planktivorous seabirds have been conducted.
Taxonomic composition of auklet diets during the breeding season reflects the life histories of their zooplankton prey (Bédard 1969b). Copepods migrate to the epipelagic layer (0 to $100 \mathrm{~m}$ ) in summer (July to August) to graze on phytoplankton. The combined biomass of the largest copepod species (e.g. Neocalanus cristatus, N. flemingeri, N. plumchrus, Eucalanus bungii) can reach $90 \%$ or more of total zooplankton biomass (Coyle et al. 1996). Large herbivorous copepods, such as N. cristatus, are typically restricted to oceanic and outer shelf domains (Springer \& Roseneau 1985) but are transported to shallower depths near St. Lawrence Island by the turbulent advection of oceanic water in the Anadyr Current (Coyle et al. 1996). Several studies have described auklet diet composition (Bédard 1969b, Piatt et al. 1988, Hunt \& Harrison 1990, Obst et al. 1995), but there are few data on seasonal or annual variation in auklet diets in the northern Bering Sea, and no studies have investigated the relationship between diet and chick survival.

We studied breeding biology of least and crested auklets on St. Lawrence Island, Alaska during 2000 to 2002 to evaluate the relationship between variation in auklet reproductive parameters and variation in their diet, which presumably reflects changes in the zooplankton community of the northern Bering Sea. Our objectives were (1) to quantify interannual variation in taxonomic composition of auklet prey, (2) to assess interannual variation in auklet breeding chronology and survival of eggs and chicks, and (3) to quantify the relationship between auklet diet and daily chick survival rates.

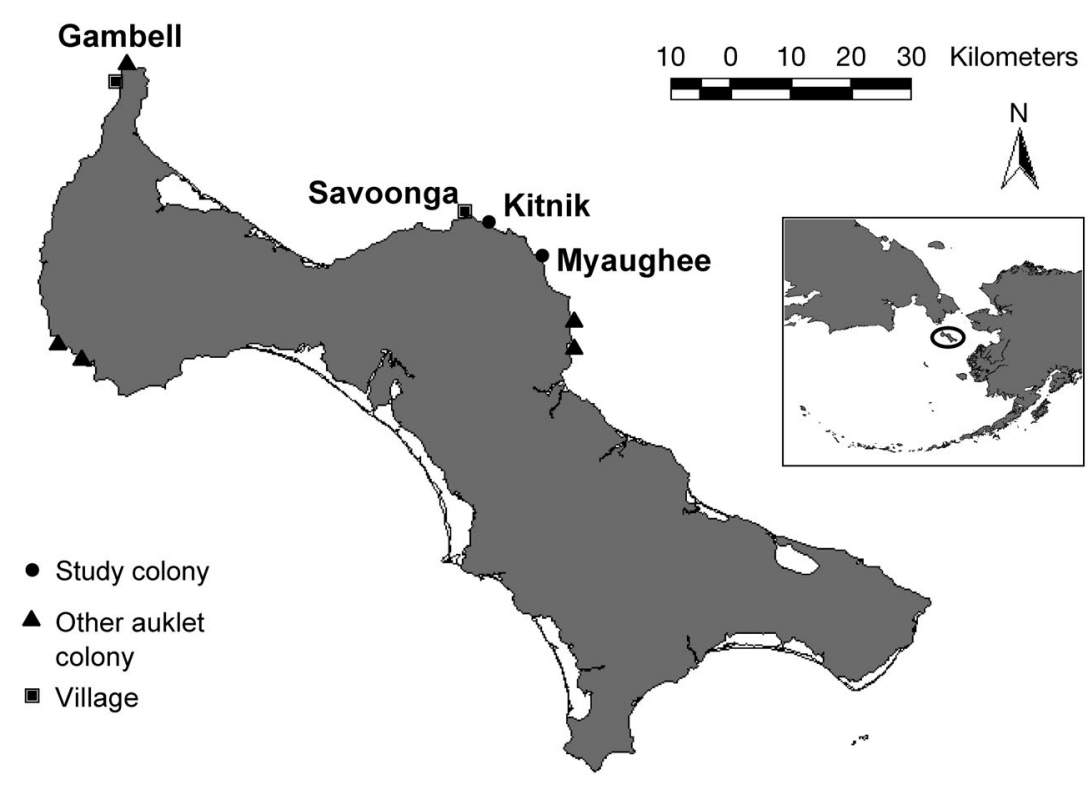

Fig. 1. St. Lawrence Island, Alaska (ca. $63^{\circ} 30^{\prime} \mathrm{N}, 170^{\circ} 30^{\prime} \mathrm{W}$ ), showing location of Kitnik and Myaughee study colonies 


\section{MATERIALS AND METHODS}

Study area. St. Lawrence Island (ca. $63^{\circ} 30^{\prime} \mathrm{N}$, $170^{\circ} 30^{\prime} \mathrm{W}$ ) is located ca. $200 \mathrm{~km}$ west of the coast of Alaska and about $60 \mathrm{~km}$ east of the Chukotsk Peninsula, Siberia. We studied auklets at 2 breeding colonies on the north coast of St. Lawrence Island, east of the village of Savoonga (Fig. 1). The Kitnik colony is located ca. 6 to $8 \mathrm{~km}$ east of the village of Savoonga and west of the mouth of the Kitnik River. Auklets at this colony nest among boulders and talus that extend for ca. $1500 \mathrm{~m}$ along the coast and slope upward from the coastline/riverbed for $100 \mathrm{~m}$ before leveling off. The Myaughee colony is located ca. 17 to $20 \mathrm{~km}$ east of Savoonga in a level area of boulders interspersed with vegetation extending from the Maghaq River valley about $3 \mathrm{~km}$ eastward to Cape Myaughee.

Diet composition. Breeding adult auklets carry food in a sublingual throat pouch to provision their chicks until fledging and readily regurgitate the chick meal when captured. Chick meals were used to sample auklet diet and were collected from captured adults approx. every $3 \mathrm{~d}$ during the chick-rearing period from late July until late August. Adults were captured either by using noose mat traps on display rocks or with mist nets set up on the colony. Auklets were trapped on $10 \mathrm{~d}$ in 2000, 9 d in 2001, and 15 d in 2002. Auklets were released after collection of their chick meal.

Regurgitated chick meals were collected in separate plastic bags. In 2000 and 2001, chick meal samples were preserved by freezing after collection. In 2002, chick meal samples were preserved in $70 \%$ isopropyl alcohol immediately after collection to minimize breakdown of prey items.

Prey items in chick meals were counted and identified to the lowest possible taxonomic group by K. R. Turco of Alaska's Spirit Speaks: Sound and Science, Fairbanks, Alaska. Prey identification was verified by K. O. Coyle of the Institute of Marine Science, University of Alaska Fairbanks. Each prey type was further sorted by size (Table 1). When individual prey items could not be identified to species, they were placed in a non-specific genus category. Thysanoessa raschii was the only species of euphausiid positively identified in our samples. In some samples, euphausiids could not be sorted by size because they were broken or had parts missing. Broken specimens were assigned to either the Thysanoessa spp. prey type or the Euphausiid spp. prey type based on how reliably the remaining parts could be identified.

Calanoid copepods in diet samples belonged to one of 2 genera: Neocalanus or Calanus. The species $N$. flemingeri and $N$. plumchrus are taxonomically distinct (Miller 1993), but they are very similar and difficult to distinguish in auklet diet samples. N. flemingeri is more common in waters around St. Lawrence Island (K. O. Coyle pers. comm.), so we assumed that copepods identified as either $N$. flemingeri or $N$. plumchrus were $N$. flemingeri. The Copepod spp. prey type included individuals that could not be identified to species but were $N$. flemingeri, $N$. plumchrus, or $C$. marshallae. $N$. cristatus individuals were twice the size of the other copepod species and easily distinguished from the species in the copepod spp. prey type (K. R. Turco pers. comm.). Most of the amphipods in auklet diet samples were identified as Themisto libellula. Amphipods that could not be positively identified to species were small, similar in size, and placed in the prey type Themisto spp.

Statistical analyses of diet. We used the average mass of each prey type from preserved samples collected from the Bering Sea during late July and

Table 1. Prey type categories used to sort least and crested auklet diet samples collected during the 2000 to 2002 breeding seasons on St. Lawrence Island, Alaska. Mass values represent average mass (mg) of each prey type determined from preserved samples collected from Bering Sea during 1997 to 1999 (K. Coyle, Institute of Marine Science, University of Alaska, Fairbanks, unpubl. data)

\begin{tabular}{|c|c|c|}
\hline Prey type & $\begin{array}{l}\text { Length } \\
\text { (mm) }\end{array}$ & $\begin{array}{r}\text { Mass } \\
(\mathrm{mg})\end{array}$ \\
\hline Themisto libellula $^{\mathrm{a}}$ & $>12$ & 167.0 \\
\hline Themisto libellula & $<7$ & 32.3 \\
\hline Themisto spp. & $<4$ & 3.9 \\
\hline Parathemisto pacifica & $<4$ & 3.7 \\
\hline Thysanoessa raschii & $>12$ & 97.9 \\
\hline Thysanoessa raschii & $<7$ & 30.5 \\
\hline Thysanoessa spp. & $>10$ & 79.0 \\
\hline Euphausiid spp. & $<7$ & 22.7 \\
\hline Larval shrimp & $<7$ & 12.0 \\
\hline Neocalanus cristatus & & 17.6 \\
\hline Neocalanus flemingeri ${ }^{\mathrm{b}}$ & & 3.8 \\
\hline Calanus marshallae & & 1.8 \\
\hline \multicolumn{3}{|l|}{ Copepod spp. ${ }^{\mathrm{C}}$} \\
\hline Diastylis bidentata & & 5.4 \\
\hline Calliopus laevisculus & & 2.2 \\
\hline Ansiogammarus pugetensis & & 2.2 \\
\hline Ischyrocerus spp. & & 2.2 \\
\hline Pontegenia spp. & & 2.2 \\
\hline Ericthonius hunteri & & 2.2 \\
\hline Pandalid (shrimp) & $>12$ & 48.7 \\
\hline Crangonid megalopa (crab) & & 15.0 \\
\hline Brachyuran zoea (crab) & & 1.0 \\
\hline Pagurid (larval hermit crab) & & 1.0 \\
\hline Crangonidae (crab) & & 5.0 \\
\hline Larval fish & $20-30$ & 475.0 \\
\hline Pteropod & & 1.0 \\
\hline \multicolumn{3}{|c|}{$\begin{array}{l}\text { bMay include } N \text {. plumchrus, which were not distinguished } \\
\text { from } N \text {. flemingeri in this study }\end{array}$} \\
\hline \multicolumn{3}{|c|}{$\begin{array}{l}{ }^{c} \text { Average mass for this prey type was calculated for each } \\
\text { sample proportional to number of prey items identified as } \\
N \text {. flemingeri and } C \text {. marshallae and using average per- } \\
\text { item mass for these } 2 \text { prey types }\end{array}$} \\
\hline
\end{tabular}


August, 1997-1999 (K. O. Coyle, Institute of Marine Science, unpubl. data) to convert number of items of each prey type to biomass estimates (Table 1). Prey items recovered from auklets were rarely intact, precluding collection of mass for each prey type from our samples. The proportion of biomass in the copepod spp. prey type that was attributable to Neocalanus flemingeri and Calanus marshallae was calculated for each meal based on the proportions of $N$. flemingeri and C. marshallae present in the portion of the sample that could be identified to species. Aggregate percentage of prey biomass (APB) represented by each prey type was calculated to give equal weight to all chick meal samples (Swanson et al. 1974):

$$
\mathrm{APB}=\sum_{i=1}^{N} p_{i} / N \times 100
$$

where $p_{i}$ is the biomass proportion of the prey type in the $i$ th sample and $N$ is the total number of samples.

We grouped prey types into 6 categories for comparison among years: (1) gammarid amphipods (primarily Themisto libellula), (2) euphausiids (primarily Thysanoessa raschii), (3) Neocalanus cristatus, (4) N. flemingeri, (5) Calanus marshallae, and (6) other prey (including larval shrimp, fish, crabs, and clams). APB values were logit transformed for analysis to normalize the distribution of proportions (Ramsey \& Schafer 2002). We used ANOVAs with Tukey-Kramer procedures for multiple comparisons of means to compare diet composition among years (Ramsey \& Schafer 2002). We established $p=0.05$ a priori as our level of significance for statistical tests.

Nest chronology and survival. Study plots within each colony were selected to include a variety of talus sizes that provide nesting habitat for both least and crested auklets. Crested auklets (ca. $280 \mathrm{~g}$ ) are about 3 times larger than least auklets (ca. $85 \mathrm{~g}$ ) and nest in larger crevices (Bédard 1969a, Byrd et al. 1983, Piatt et al. 1990). Active nest crevices were located at each colony by searching talus and boulder fields using high-powered flashlights during the mid-incubation period. Searching for nests during mid-incubation reduces investigator disturbance during laying and early incubation, which can disrupt incubation activities and reduce hatching success (Piatt et al. 1990).

Each crevice found to contain an adult incubating an egg was included in the sample of active nest sites. If we were unable to see the egg, then an adult observed in the same crevice on 2 consecutive visits was assumed to be incubating an egg. Unattended eggs were touched, if possible, to determine if they were warm and thus being incubated. Cold eggs were monitored, but if no adult was seen attending the egg, it was discarded from the sample, as it might have been from the previous breeding season (Williams et al. 2000).
Nests at the Kitnik colony were checked once every $4 \mathrm{~d}$ until $1 \mathrm{wk}$ before the expected median hatch date, based on dates provided by previous studies on St. Lawrence Island (Bédard 1969a, Sealy 1975, Piatt et al. 1990). We increased nest check frequency to every other day during the hatching period (approx. 20 July to 15 August) to determine hatching dates more precisely. Hatch dates were used to extrapolate laying dates and expected fledging dates, using the average duration of incubation and nestling periods, respectively, from previous studies (Bédard 1969a, Sealy 1975, Piatt et al. 1990).

After chicks hatched, nests at the Kitnik colony were checked once every $4 \mathrm{~d}$ throughout the chick-rearing period to record status (active vs. failed). Nests were recorded as active if chicks were seen or heard in the crevice or if fresh excreta or chick dander was present. When chicks were $22 \mathrm{~d}$ old, we increased nest check frequency to every other day to determine fledging date more precisely. Nests that were recorded as inactive on 2 consecutive visits after $24 \mathrm{~d}$ of age (least auklets) or $26 \mathrm{~d}$ of age (crested auklets) were considered fledged. In 2001 and 2002, nests at the Myaughee colony were checked less frequently due to logistical constraints.

Statistical analyses of nest survival. Nest survival during incubation and chick-rearing stages were estimated separately, rather than analyzing nest survival over the entire breeding period, for 2 reasons. First, many nests that failed during incubation contained eggs that failed to hatch, rather than eggs that were destroyed, making nest fate difficult to determine until the end of incubation. Second, we collected data on diet composition only during chick rearing and could not, therefore, infer the effects of diet on nesting success during incubation.

We expected survival of eggs and chicks to differ among years (YEAR) due to potential annual variation in factors such as weather, nest predator numbers, and food availability. We also evaluated variation in nest survival between the Kitnik and Myaughee colonies (SITE), potentially related to local-scale variables, such as proximity to arctic fox Alopex lagopus dens and numbers of alternative prey available to predators.

We estimated survival of eggs in the nest during incubation for each combination of site and year using generalized linear models with a logit link fit in the program MARK (Dinsmore et al. 2002), adjusted for the proportion of eggs that failed to hatch. We modeled survival of eggs in the nest as a function of YEAR and SITE. We only considered this model because there were few incidences of nest mortality to support more complex models of daily survival. Differences among sites and among years were an a priori assumption and supported by models of chick survival (see next 
subsection). In site-years where all egg mortality was attributed to abandonment or egg failure, we calculated nest survival during incubation as the proportion of eggs found during mid-incubation that hatched. In site-years where there was egg loss during incubation, in addition to eggs that failed to hatch, nest survival during incubation for each site-year was calculated as the product of the proportion of eggs that hatched and the model estimate of egg survival.

We estimated chick survival (i.e. the probability that a nest where an egg hatched will fledge a chick) using maximum likelihood estimators from generalized linear models fit in the program MARK (Dinsmore et al. 2002). These models use a logit link to relate covariates to the binomial response (Cooch \& White 2005). We explored variation in daily survival rate (DSR) of chicks at the nest within stages of chick rearing (early and late), among years, between sites, and in relation to the prevalence of oceanic copepods in chick meals.

We modeled chick survival as a function of YEAR, SITE, and a temporal variable to explore intra-annual variation in DSR. After hatching, auklet chicks are most vulnerable to mortality during the first $10 \mathrm{~d}$ of the nestling period (Fraser et al. 2002), which would lead to lower daily survival rates early in the nesting period. We divided the chick-rearing stage into 2 periods: (1) early chick rearing (chick age 1 to $15 \mathrm{~d}$ ) and (2) late chick rearing. This division corresponds to approx. half of the chick-rearing period for both species. This 2period division of the chick-rearing period was specified by the temporal variable 2-STAGE.

We constructed the general model that included YEAR, SITE, 2-STAGE, and an interaction between YEAR and SITE. We consecutively dropped out the interaction terms and, where possible, the main effects, using Akaike's Information Criterion corrected for small sample sizes $\left(\mathrm{AIC}_{\mathrm{c}}\right)$, which uses the principle of parsimony to balance model fit (model likelihood) with model complexity (number of parameters) to select the model best supported by the data (Burnham \& Anderson 2002). We also included a model specifying constant survival to confirm that significant variation in nest survival was explained by the other models in the candidate set. Models were weighted based on the difference between each model's $\mathrm{AIC}_{\mathrm{C}}$ value and that of the top-ranked model, and the weights were normalized to sum to 1 over all models considered (Burnham \& Anderson 2002). The model with the lowest $\mathrm{AIC}_{\mathrm{C}}$ value was selected as the best approximating model given the data, and models within $2 \mathrm{AIC}_{\mathrm{C}}$ units of the top-ranked model were considered well supported by the data for drawing inferences (Burnham \& Anderson 2002).

To test the hypothesis that chick DSR is positively associated with the prevalence of oceanic copepods in the diet, we added diet composition to the best approximating model from the process described above. We hypothesized that the proportion of Neocalanus copepods fed to chicks would be associated with increased chick DSR, because this genus has high lipid content relative to other zooplankton found in auklet diets (Obst et al. 1995). The high lipid content of Neocalanus copepods may provide more energy for foraging activities of chick-rearing adults, as well as the growth and survival of chicks, than other prey types. Least auklets breeding on St. Lawrence Island consume both $N$. cristatus, an oceanic copepod characteristic of water advected by the Anadyr current (Springer et al. 1989) and Calanus marshallae, a copepod associated with Bering Shelf water (Bédard 1969b, Hunt et al. 1990, Piatt et al. 1990). Therefore, we included the proportions of N. cristatus (CRIS) and C. marshallae (MARS) in diet samples by mass as covariates in the models to evaluate the variation in chick survival associated with variation in these prey types among years. For crested auklets, we included the proportion of $N$. cristatus (CRIS) in the diet in models of chick survival. Crested auklets consume primarily euphausiids during the breeding season, but the proportion of $N$. cristatus in chick meals varies more than the proportion of euphausiids among years and has been positively associated with reproductive success of crested auklets (Fraser et al. 2002).

Variables for YEAR and diet composition (CRIS, MARS) were highly correlated and therefore were not included in models together. Including year and diet variables in separate models allows evaluation of the relative effect of year, which is likely related to a suite of factors such as phenology, weather, predation, as well as diet, on the effects of diet alone. We used model-averaged estimates from the candidate model set to draw inference about variation in chick DSR. Model-averaged estimates account for model selection uncertainty (Burnham \& Anderson 2002). Confidence intervals of survival estimates were calculated using the delta method (Seber 1982, Traylor et al. 2004). We report mean values as $\pm 1 \mathrm{SE}$ unless otherwise stated.

\section{RESULTS}

\section{Diet composition}

There were no differences in diet between the 2 colonies for either species in any year ( $p>0.1$ for all comparisons). Therefore, we pooled diet samples across sites for comparisons among years. Least auklet diets consisted mostly of calanoid copepods in each year of the study, based on aggregate percent biomass (APB) (Fig. 2, Tables 2 \& 3). The oceanic copepod Neo- 
calanus flemingeri was the single most prevalent prey type in all 3 yr of the study (2000: $41 \%$ APB, 2001: $38 \%$ APB, 2002: $62 \%$ APB), but the relative proportions of this and other prey categories differed among years (Fig. 2). In 2002, a year of high reproductive success for auklets, oceanic copepods $N$. cristatus $(21 \%$ ABP,
$\left.F_{2,190}=5.72, \mathrm{p}=0.002\right)$ and $N$. flemingeri $\left(F_{2,190}=15.12\right.$, $\mathrm{p}<0.001$ ) were more prevalent in the diet than in the previous 2 yr. In 2001, the year of poorest reproductive success, oceanic copepods were less abundant $(N$. cristatus $=8 \%$ APB) and the small, neritic copepod Calanus marshallae made up a substantial portion of

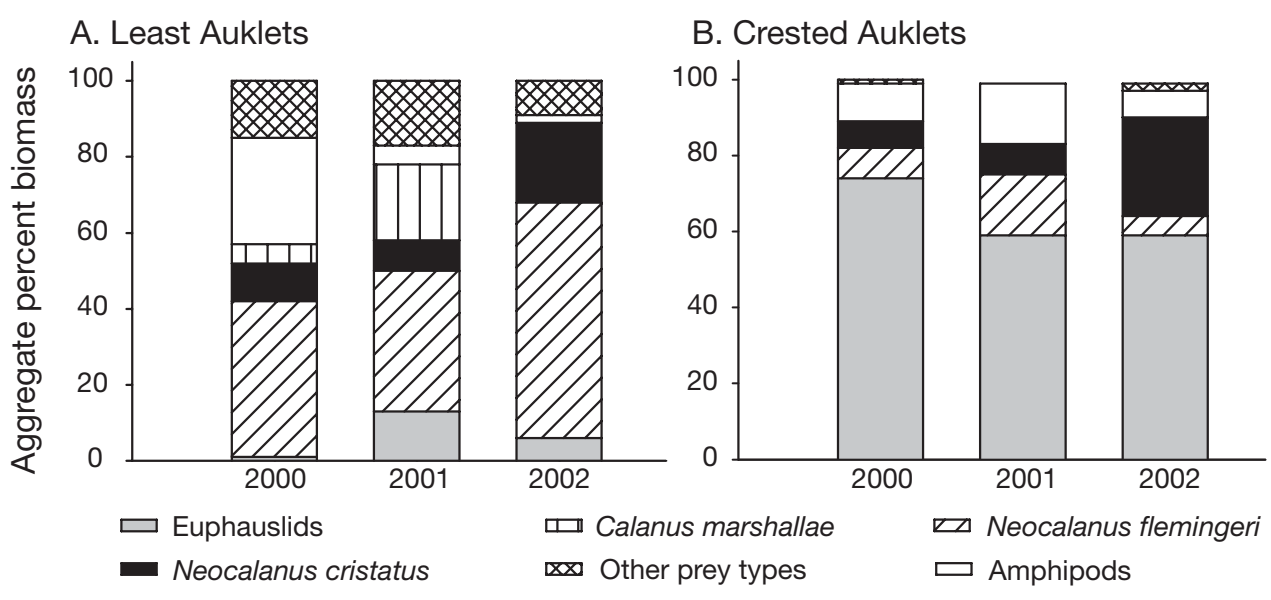

Fig. 2. (A) Aethia pusilla and (B) A. cristatella. Interannual differences in taxonomic composition by biomass of diets fed to chicks on St. Lawrence Island, Alaska from late July through August 2000, 2001, and 2002

Table 2. Aethia pusilla. Taxonomic composition of meals delivered to chicks during the 2000 to 2002 breeding seasons on St. Lawrence Island, Alaska. Data are expressed as aggregate percent biomass with $95 \%$ confidence intervals in parentheses

\begin{tabular}{|c|c|c|c|}
\hline Prey category & $\begin{array}{c}2000 \\
(\mathrm{n}=77)\end{array}$ & $\begin{array}{c}2001 \\
(\mathrm{n}=71)\end{array}$ & $\begin{array}{c}2002 \\
(\mathrm{n}=45)\end{array}$ \\
\hline Amphipods ${ }^{\mathrm{a}}$ & $\begin{array}{c}28.5 \\
( \pm 5.9)\end{array}$ & $\begin{array}{c}4.5 \\
( \pm 2.7)\end{array}$ & $\begin{array}{c}1.9 \\
( \pm 1.6)\end{array}$ \\
\hline Euphausiids $^{\mathrm{b}}$ & $\begin{array}{c}1.5 \\
( \pm 1.8)\end{array}$ & $\begin{array}{c}13.3 \\
( \pm 5.2)\end{array}$ & $\begin{array}{c}5.9 \\
( \pm 4.3)\end{array}$ \\
\hline Calanoid copepods ${ }^{\mathrm{c}}$ & $\begin{array}{c}55.3 \\
( \pm 5.5)\end{array}$ & $\begin{array}{c}65.4 \\
( \pm 7.5)\end{array}$ & $\begin{array}{c}83.2 \\
( \pm 5.2)\end{array}$ \\
\hline Neocalanus cristatus & $\begin{array}{c}9.8 \\
( \pm 4.1)\end{array}$ & $\begin{array}{c}7.9 \\
( \pm 2.6)\end{array}$ & $\begin{array}{c}21.3 \\
( \pm 9.1)\end{array}$ \\
\hline Neocalanus flemingeri $^{\mathrm{d}}$ & $\begin{array}{c}41.0 \\
( \pm 5.5)\end{array}$ & $\begin{array}{c}37.6 \\
( \pm 6.9)\end{array}$ & $\begin{array}{c}61.8 \\
( \pm 8.9)\end{array}$ \\
\hline Calanus marshallae & $\begin{array}{c}4.5 \\
( \pm 2.8)\end{array}$ & $\begin{array}{c}20.1 \\
( \pm 6.1)\end{array}$ & 0.0 \\
\hline Other prey types ${ }^{\mathrm{e}}$ & $\begin{array}{c}14.7 \\
( \pm 3.8)\end{array}$ & $\begin{array}{c}16.7 \\
( \pm 5.3)\end{array}$ & $\begin{array}{c}8.8 \\
( \pm 3.4)\end{array}$ \\
\hline \multicolumn{4}{|c|}{$\begin{array}{l}\text { a Primarily Themisto libellula } \\
\text { bPrimarily Thysanoessa raschii } \\
{ }^{c} \text { Includes Neocalanus cristatus, N. flemingeri, Calanus } \\
\text { marshallae, and Copepod spp. prey types } \\
\text { d'May also include N. plumchrus } \\
\text { e Includes Diastylis bidentata, Calliopus laevisculus, } \\
\text { Ansiogammarus pugetensis, Ischyrocerus spp., Pontege- } \\
\text { nia spp., Ericthonius hunteri, pandalid shrimp, crangonid } \\
\text { megalopa, brachyuran zoea, pagurid crab, crangonid } \\
\text { crab, larval fish, and pteropod }\end{array}$} \\
\hline
\end{tabular}

Table 3. Aethia cristatella. Taxonomic composition of meals delivered to nestlings during the 2000 to 2002 breeding seasons on St. Lawrence Island, Alaska. Data expressed as aggregate percent biomass with $95 \%$ confidence intervals in parentheses

\begin{tabular}{|c|c|c|c|}
\hline Prey category & $\begin{array}{c}2000 \\
(\mathrm{n}=29)\end{array}$ & $\begin{array}{c}2001 \\
(\mathrm{n}=42)\end{array}$ & $\begin{array}{c}2002 \\
(\mathrm{n}=44)\end{array}$ \\
\hline Amphipods $^{\mathrm{a}}$ & $\begin{array}{c}9.9 \\
( \pm 8.7)\end{array}$ & $\begin{array}{c}16.2 \\
( \pm 8.6)\end{array}$ & $\begin{array}{c}7.2 \\
( \pm 6.0)\end{array}$ \\
\hline Euphausiids $^{\mathrm{b}}$ & $\begin{array}{c}73.5 \\
( \pm 11.9)\end{array}$ & $\begin{array}{c}59.5 \\
( \pm 11.9)\end{array}$ & $\begin{array}{c}59.4 \\
( \pm 12.0)\end{array}$ \\
\hline Calanoid copepods ${ }^{\mathrm{c}}$ & $\begin{array}{c}15.9 \\
( \pm 5.8)\end{array}$ & $\begin{array}{c}24.1 \\
( \pm 9.5)\end{array}$ & $\begin{array}{c}31.0 \\
( \pm 9.7)\end{array}$ \\
\hline Neocalanus cristatus & $\begin{array}{c}7.0 \\
( \pm 2.7)\end{array}$ & $\begin{array}{c}8.2 \\
( \pm 4.5)\end{array}$ & $\begin{array}{c}26.3 \\
( \pm 9.4)\end{array}$ \\
\hline Neocalanus flemingeri $^{\mathrm{d}}$ & $\begin{array}{c}8.6 \\
( \pm 4.6)\end{array}$ & $\begin{array}{c}16.0 \\
( \pm 7.0)\end{array}$ & $\begin{array}{c}4.7 \\
( \pm 3.8)\end{array}$ \\
\hline Calanus marshallae & $\begin{array}{c}0.2 \\
( \pm 0.2)\end{array}$ & 0.0 & 0.0 \\
\hline Other prey types ${ }^{\mathrm{e}}$ & $\begin{array}{c}0.7 \\
( \pm 1.3)\end{array}$ & $\begin{array}{c}0.2 \\
( \pm 0.2)\end{array}$ & $\begin{array}{c}2.4 \\
( \pm 1.9)\end{array}$ \\
\hline \multicolumn{4}{|c|}{ 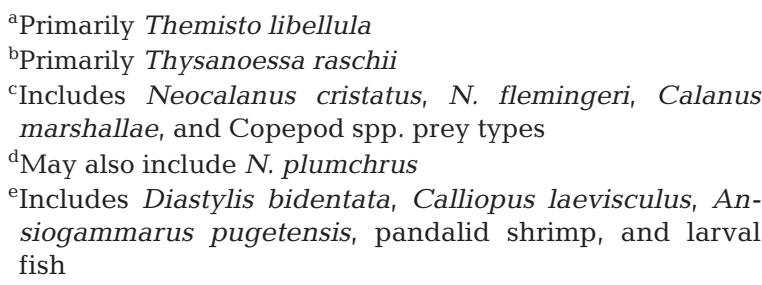 } \\
\hline
\end{tabular}


the least auklet diet $\left(20 \% \mathrm{ABP}, F_{2,190}=13.52, \mathrm{p}<\right.$ 0.001). Amphipods comprised $28.5 \%$ of least auklet diets in 2000, but only $4.5 \%$ in 2001 and $2.0 \%$ in 2002 (Fig. 2). Perhaps most striking was the complete absence of $C$. marshallae in least auklet chick meals collected in 2002, despite the very high prevalence of calanoid copepods in the diet that year (Fig. 2).

Crested auklet diets consisted mostly of euphausiids (primarily Thysanoessa raschii) in all 3 yr of the study, comprising $74 \%$ ABP in 2000, $60 \%$ ABP in 2001, and $59 \%$ APB in 2002 (Fig. 2). Copepods were the next most prevalent prey category in the diet of crested auklets, and species composition of the copepod portion of the diet differed among years. Neocalanus cristatus was more prevalent in crested auklet diets in 2002 (26\% APB) than in 2000 (7\% APB) or 2001 (8\% APB, $p<0.001)$, the same pattern as in least auklet diets. In contrast, the smaller copepod $N$. flemingeri was most prevalent in 2001 (16\% APB), compared to $9 \%$ APB in 2000 and 5\% APB in 2002.

\section{Nesting chronology and nest survival}

There was high hatching synchrony for both least and crested auklets in all 3 yr of the study. The median hatch dates for least and crested auklets were 6 to $10 \mathrm{~d}$ earlier in 2002 compared to the previous 2 yr (Table 4). There were no differences in timing of breeding between the 2 colonies for either species. Results presented in Table 4 are for the Kitnik colony, which was monitored more frequently and provided more precise estimates of median hatching and fledging dates

Average reproductive success was generally high ( $>65 \%$ of monitored nests fledged young) for both auklet species during the 3 yr study. Overall nest survival of least auklets was higher than that of crested auklets at both colonies in most years, primarily because of higher hatching success (Table 5). For both species, eggs failed to hatch in all years and at both sites. However, there was no apparent loss of least auklet eggs due to predation at the Kitnik colony in 2000 , or at either colony in 2002. In contrast, we suspect that crested auklet eggs were depredated during incubation in all years at both sites. Overall estimates of nest survival for both species of auklets were 10 to 20 percentage points higher in 2002 than in the previous 2 yr (Table 5).

Variation in daily survival rate (DSR) of least auklet chicks was best explained by diet composition, colony site, and the 2-stage division of the nestling period (Table 6). The model including the variable for the proportions of Neocalanus cristatus in the diet was as well supported by the data as the model including YEAR, indicating that the diet variable explained as much of the variation in chick DSR as did YEAR (Table 6).

Substituting the proportion of $\mathrm{NeO}$ calanus cristatus for YEAR in the top-ranked model improved model fit $(\Delta \mathrm{AIC}=0.8)$, providing some support for a positive effect of $N$. cristatus on DSR of least auklet chicks (Fig. 3). When YEAR was included in the model rather than diet variables, the positive parameter estimate indicated chicksurvival was highest in $2002\left(\hat{\beta}_{2002}=\right.$ $2.12,95 \% \mathrm{CI}=1.15$ to 3.08 on a logit scale), the year when Calanus marshallae was absent from the diet. The model including the effect of $C$. marshallae was not as well supported by the data, relative to models that included YEAR or CRIS $(\triangle \mathrm{AIC}=2.1)$. The estimate for the effect of $C$. marshallae on chick DSR, however, was negative and clearly different from zero $\left(\hat{\beta}_{\mathrm{MARS}}=\right.$ $-9.94,95 \% \mathrm{CI}=-14.9$ to -5.59 on a logit scale), suggesting that an increase in the proportion of $C$. marshallae in the diet was associated with reduced chick DSR for least auklets. 
Table 5. Aethia pusilla and A. cristatella. Nest survival at 2 breeding colonies on north shore of St. Lawrence Island, Alaska, USA during 2000 to 2002 breeding seasons. Estimates are from nest survival models that include effects of YEAR and SITE. Values in parentheses are $95 \%$ confidence intervals

\begin{tabular}{|c|c|c|c|c|c|c|}
\hline & 2000 & $\begin{array}{c}\text { - Kitnik - } \\
2001\end{array}$ & 2002 & 2000 & $\begin{array}{c}\text { - Myaughee - } \\
2001\end{array}$ & 2002 \\
\hline \multicolumn{7}{|l|}{ Least auklets } \\
\hline$N$ & 30 & 63 & 62 & 33 & 41 & 27 \\
\hline Incubation survival & $\begin{array}{c}0.967 \\
(0.964-0.968)\end{array}$ & $\begin{array}{c}0.636 \\
(0.516-0.706)\end{array}$ & $\begin{array}{c}0.968 \\
(0.967-0.969)\end{array}$ & $\begin{array}{c}0.813 \\
(0.611-0.908)\end{array}$ & $\begin{array}{c}0.887 \\
(0.686-0.923)\end{array}$ & $\begin{array}{c}0.926 \\
(0.921-0.931)\end{array}$ \\
\hline Chick survival & $\begin{array}{c}0.741 \\
(0.598-0.884)\end{array}$ & $\begin{array}{c}0.551 \\
(0.407-0.696)\end{array}$ & $\begin{array}{c}0.926 \\
(0.857-0.994)\end{array}$ & $\begin{array}{c}0.885 \\
(0.796-0.975)\end{array}$ & $\begin{array}{c}0.802 \\
(0.687-0.918)\end{array}$ & $\begin{array}{c}0.972 \\
(0.940-1.00)\end{array}$ \\
\hline Nest survival & $\begin{array}{c}0.72 \\
(0.50-0.86)\end{array}$ & $\begin{array}{c}0.35 \\
(0.46-0.87)\end{array}$ & $\begin{array}{c}0.90 \\
(0.78-0.94)\end{array}$ & $\begin{array}{c}0.72 \\
(0.46-0.87)\end{array}$ & $\begin{array}{c}0.71 \\
(0.40-0.83)\end{array}$ & $\begin{array}{c}0.90 \\
(0.84-0.92)\end{array}$ \\
\hline \multicolumn{7}{|l|}{ Crested auklets } \\
\hline$N$ & 33 & 49 & 65 & 54 & 50 & 40 \\
\hline Incubation survival & $\begin{array}{c}0.837 \\
(0.663-0.829)\end{array}$ & $\begin{array}{c}0.687 \\
(0.598-0.727)\end{array}$ & $\begin{array}{c}0.921 \\
(0.834-0.953)\end{array}$ & $\begin{array}{c}0.710 \\
(0.605-0.765)\end{array}$ & $\begin{array}{c}0.826 \\
(0.680-0.893)\end{array}$ & $\begin{array}{c}0.775 \\
(0.643-0.825)\end{array}$ \\
\hline Chick survival & $\begin{array}{c}0.865 \\
(0.725-0.999)\end{array}$ & $\begin{array}{c}0.787 \\
(0.620-0.954)\end{array}$ & $\begin{array}{c}0.908 \\
(0.828-0.989)\end{array}$ & $\begin{array}{c}0.934 \\
(0.854-1.00)\end{array}$ & $\begin{array}{c}0.885 \\
(0.787-0.982)\end{array}$ & $\begin{array}{c}0.954 \\
(0.900-1.00)\end{array}$ \\
\hline Nest survival & $\begin{array}{c}0.72 \\
(0.41-0.78)\end{array}$ & $\begin{array}{c}0.54 \\
(0.34-0.63)\end{array}$ & $\begin{array}{c}0.84 \\
(0.51-0.84)\end{array}$ & $\begin{array}{c}0.66 \\
(0.48-0.75)\end{array}$ & $\begin{array}{c}0.73 \\
(0.51-0.84)\end{array}$ & $\begin{array}{c}0.74 \\
(0.57-0.81)\end{array}$ \\
\hline
\end{tabular}

Daily nest survival was higher during late chick rearing $\left(\hat{\beta}_{\text {late }}=1.40,95 \% \mathrm{CI}-0.31\right.$ to 3.11$)$, compared to the first $15 \mathrm{~d}$ of chick rearing, There is also some evidence that least auklet nests at the Myaughee colony had higher DSRs than nests at the Kitnik colony, particularly in $2001\left(\hat{\beta}_{\text {Myaughee }}=0.95,95 \% \mathrm{CI}-0.07\right.$ to 1.97$)$, though the $95 \%$ confidence intervals of both estimates include 0 .

The best-fitting model that explained variation in chick DSR of crested auklets included SITE, YEAR, and the 2-stage division of the chick-rearing period (Table 7). As with least auklet chicks, crested auklet chick DSR was highest in $2002\left(\hat{\beta}_{2002}=1.14,95 \% \mathrm{CI}=\right.$ 0.08 to 2.19 on a logit scale) and was higher at the Myaughee colony compared to the Kitnik colony $\left(\hat{\beta}_{\text {Myaughee }}=0.78,95 \% \mathrm{CI}=-0.15\right.$ to 1.72 on a logit scale). There is weak evidence that annual variation in chick DSR was associated with the proportion of $N$. cristatus in the diet (Fig. 3). The model including CRIS was not as strongly supported by the data as the model including YEAR $(\triangle \mathrm{AIC}=2.2)$, suggesting that other factors in addition to the proportion of $N$. cristatus in the diet influenced variation in chick DSR of crested auklets.
Table 6. Aethia pusilla. Model selection results for factors affecting chick survival on St. Lawrence Island, Alaska, 2000 to 2002. Models are ranked by ascending Akaike's Information Criterion $\left(\Delta \mathrm{AIC}_{\mathrm{c}}\right)$, the difference between the $\mathrm{AIC}_{\mathrm{C}}$ value of a given model and the model with the lowest $\mathrm{AIC}_{\mathrm{C}}$. $\mathrm{AIC}_{\mathrm{C}}$ weight indicates relative support for each model given the model set. Factors in models were YEAR, nesting colony (SITE), 2-stage time trend (2-STAGE), proportion of Neocalanus cristatus in meals delivered to chicks (CRIS), proportion of Calanus marshallae (MARS), and constant (CONST). Number of parameters equals number of coefficients in model plus intercept

\begin{tabular}{|lcccrc|}
\hline Model & Deviance & $\begin{array}{c}\text { No. para- } \\
\text { meters }\end{array}$ & $\mathrm{AIC}_{\mathrm{c}}$ & $\Delta \mathrm{AIC}_{\mathrm{c}}$ & $\begin{array}{c}\mathrm{AIC}_{\mathrm{c}} \\
\text { weight }\end{array}$ \\
\hline SITE + 2-STAGE + CRIS & 316.38 & 4 & 324.38 & 0.00 & 0.46 \\
SITE + 2-STAGE + YEAR & 315.22 & 5 & 325.23 & 0.85 & 0.30 \\
SITE + 2-STAGE + MARS & 318.57 & 4 & 326.58 & 2.19 & 0.15 \\
SITE $\times$ YEAR + 2-STAGE & 314.79 & 7 & 328.81 & 4.42 & 0.05 \\
SITE + YEAR & 321.91 & 4 & 329.91 & 5.53 & 0.03 \\
SITE $\times$ YEAR & 321.30 & 6 & 333.32 & 8.93 & 0.01 \\
YEAR & 330.54 & 3 & 336.55 & 12.16 & 0.00 \\
CONST & 352.81 & 1 & 354.81 & 30.43 & 0.00 \\
\hline
\end{tabular}

\section{DISCUSSION}

While the general taxonomic composition of auklet diets described in this study was similar to that reported by Bédard (1969b) and Piatt et al. (1988), we found significant variation among years in proportions of prey types delivered to chicks. All major prey categories for least auklets varied among years, including the prevalence of copepods, the mainstay of the diet for this species (Jones 1993b). In 2001, the year of lowest chick survival for least auklets, the oceanic copepod Neocalanus flemingeri was less prevalent in the diet than in the other 2 yr of the study. Instead, least auklets consumed 


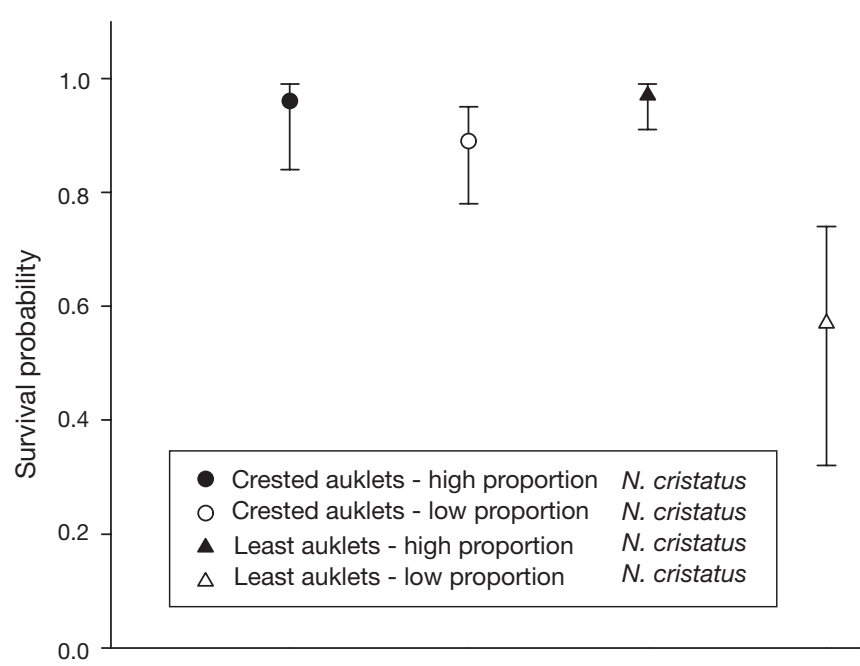

Fig. 3. Aethia pusilla and A. cristatella. Influence of Neocalanus cristatus on survival of auklet chicks on St. Lawrence Island, Alaska. Estimates $\pm 95 \%$ confidence intervals from top-ranked model that included effects of 2-STAGE, SITE, and proportion of $N$. cristatus in diet

higher proportions of the neritic copepod Calanus marshallae, which are smaller than $N$. plumchrus/flemingeri (Lee 1975). In 2002, the year of highest chick survival, large oceanic Neocalanus spp. copepods predominated in least auklet chick meals and no C. marshallae were found in any of our samples. Chick meals in 2000 had higher proportions of amphipods than C. marshallae, and while chick survival was lower than in a year with high $N$. cristatus (2002), survival was comparable to 2001. Indeed, the relationship between survival of least auklet chicks and composition of chick diets was supported by our models of chick survival, which indicated that the proportion of oceanic $N$. cristatus in chick meals was positively associated with daily survival rate of chicks.

Table 7. Aethia cristatella. Model selection results for factors affecting chick survival on St. Lawrence Island, Alaska, 2000 to 2002. Models are ranked by ascending $\triangle \mathrm{AIC}_{\mathrm{C}}$, the difference between the $\mathrm{AIC}_{\mathrm{c}}$ value of a given model and the model with the lowest $\mathrm{AIC}_{\mathrm{c}}$. $\mathrm{AIC}_{\mathrm{c}}$ weight indicates relative support for each model given the model set. Other explanations as in Table 6

\begin{tabular}{|lccccc|}
\hline Model & Deviance & $\begin{array}{c}\text { No. para- } \\
\text { meters }\end{array}$ & $\mathrm{AIC}_{\mathrm{c}}$ & $\Delta \mathrm{AIC}_{\mathrm{c}}$ & $\begin{array}{c}\mathrm{AIC}_{\mathrm{c}} \\
\text { weight }\end{array}$ \\
\hline SITE + 2-STAGE + YEAR & 209.32 & 5 & 219.33 & 0.00 & 0.49 \\
SITE + 2-STAGE + CRIS & 213.52 & 4 & 221.53 & 2.20 & 0.16 \\
SITE $\times$ YEAR + 2-STAGE & 208.44 & 7 & 222.46 & 3.13 & 0.10 \\
SITE + YEAR & 214.76 & 4 & 222.76 & 3.44 & 0.09 \\
YEAR & 217.99 & 3 & 223.99 & 4.67 & 0.05 \\
SITE + CRIS & 218.15 & 3 & 224.15 & 4.83 & 0.04 \\
CONST & 222.20 & 1 & 224.20 & 4.87 & 0.04 \\
SITE $\times$ YEAR & 213.99 & 6 & 226.00 & 6.68 & 0.02 \\
\hline
\end{tabular}

Crested auklets consumed primarily euphausiids in each year of the study, but the proportion of the large, oceanic copepod Neocalanus cristatus varied significantly among years and was highest in 2002, the year of highest recorded chick survival. This observation is consistent with other studies, which found that diets high in $N$. cristatus were associated with high reproductive success in both crested auklets (Fraser et al. 2002) and Cassin's auklets (Ptychoramphus aleuticus; Hedd et al. 2002). In 2001, the year of lowest chick survival, the hyperiid amphipod Themisto libellula, which has smaller lipid reserves and more refractory chitin than oceanic copepods (Bédard 1969b), was more prevalent in the diet than $N$. cristatus. The correlation between chick survival and proportion of $N$. cristatus in chick diets was not as well supported for crested auklets as it was for least auklets, indicating that other components of the diet, such as euphausiids, may be more critical for survival of crested auklet chicks. Our data suggest, however, that when $N$. cristatus is readily accessible, crested auklets may become more selective and include more large copepods in the diet, thereby positively influencing their reproductive success.

Annual variability in physical oceanography of the northern Bering Sea may help explain the variation in availability of oceanic copepod prey to breeding least and crested auklets. The extent and timing of sea-ice formation in the Bering Sea is thought to exert a strong influence on copepod production in the southeastern Bering Sea (Dagg et al. 1984, Hunt et al. 2002). There is little information, however, on how these factors affect zooplankton communities on the northern Bering Sea shelf near St. Lawrence Island, where physical processes and primary production regimes are fundamentally different (Springer \& Roseneau 1985). A negative gradient in sea level from the Bering Sea to the Arctic Ocean drives a net northward transport through the Bering Strait and influences the advection of nutrientrich water carried by the Anadyr Current (Stabeno et al. 1999). In summers following seasons of extensive sea ice (e.g. 2002), primary production on the Bering shelf is concentrated along the Siberian coast from the Gulf of Anadyr to the Bering Strait. This concentration of primary production close to the northern coast of St. Lawrence Island suggests strong advection by the Anadyr current and, therefore, high availability of oceanic copepods to auklets foraging within $50 \mathrm{~km}$ of their colonies. In years following winters of limited sea ice formation (e.g. 2001), 
primary production is spread in a wide plume across large portions of the Bering shelf (Ocean ESIP 2001), suggesting weak advection of the Anadyr Current.

Advection of oceanic copepods in Anadyr water accounts for the presence of huge Aethia spp. auklet colonies on St. Lawrence Island, far from upwelling areas exploited by these species in the Aleutians and along the Bering Sea shelf edge (Piatt \& Springer 2003). Variability in the Bering Strait throughflow is attributed to the influence of local winds and the Pacific-Arctic pressure head forcing (Woodgate et al. 2005), but the influence of sea ice is not well understood. Changes in sea ice may be a factor affecting current dynamics in the northern Bering Sea, reducing the strength of advection and water column structure that make oceanic zooplankton associated with Anadyr water (especially Neocalanus spp.) available to foraging auklets.

Auklets are restricted to foraging within the upper $30 \mathrm{~m}$ of the water column (Hunt et al. 1998). Neocalanus cristatus and $N$. flemingeri are large oceanic copepods that reproduce at depths greater than $250 \mathrm{~m}$ (Miller et al. 1984) and are not commonly found in shelf waters, but advection by the Anadyr Current creates a shallow, stable water column structure in the Chirikov basin off the northern coast of St. Lawrence Island and concentrates oceanic plankton near the surface where they are accessible to avian predators (Pavlov \& Pavlov 1996). In contrast, the small Calanus marshallae is a resident neritic shelf species that feeds and reproduces throughout the summer months (Baier \& Napp 2003). In the presence of high primary production (i.e. 2001), C. marshallae may feed and reproduce continuously, leading to an abundance of this species at depths accessible to foraging auklets.

At-sea surveys have located least auklets foraging over strong, shallow thermoclines, and simultaneous acoustic surveys revealed Neocalanus spp. copepods concentrated above the thermocline (Hunt et al. 1990, 1998, Haney 1991). Least auklets have lower body mass, higher buoyancy, and poorer diving abilities than crested auklets (Hunt \& Harrison 1990), making them especially sensitive to changes in water column structure that might affect prey availability near the surface. Least auklet chick survival is positively associated with the prevalence of $N$. cristatus in the diet. If Neocalanus copepods are less accessible near St. Lawrence Island, possibly due to interannual differences in the strength and direction of the Anadyr Current, least auklets may forage on other zooplankters that occur within $15 \mathrm{~m}$ of the surface (e.g. Calanus marshallae, crab larvae, pandalid shrimp), as we observed in 2000 and 2001. Given the greater variability in their diets, least auklets appear to be more generalist foragers than crested auklets, possibly due to their poorer diving abilities. The reproductive success of least auklets was also more variable and appeared more sensitive to changes in food availability than that of crested auklets, being lowest in 2001, when we hypothesized that auklets were most food-limited.

Our estimates of overall nest survival (i.e. probability that a nest where an egg is found will fledge a chick) for least and crested auklets in 2000, 2002, and at the Myaughee colony in 2001 were higher than those reported for St. Lawrence Island in 1987 (Piatt et al. 1990), but within the range of estimated reproductive success for other colonies elsewhere in the Bering Sea (Byrd et al. 1983, Roby \& Brink 1986, Fraser et al. 1999). Overall nest survival for both least and crested auklets at the Kitnik colony in 2001, however, was the lowest recorded for either species (Jones 1993a,b). Additionally, our models indicate that daily nest survival was lower on the Kitnik colony than the Myaughee colony. Differences among colonies are likely related to local-scale factors such as proximity to fox dens, abundance of alternative prey for predators, as well as proximity to sources of anthropogenic disturbance. In least and crested auklets, frequent nest checks have been associated with reduced reproductive success (Piatt et al. 1990, Fraser et al. 1999). Models of daily nest survival can be used to directly test the hypothesis of observer effects on nest survival. In this study, we attempted to minimize this source of bias, but detecting an observer effect associated with the more frequent nest checks at the Kitnik colony is confounded by the closer proximity of Kitnik to the village of Savoonga and related sources of nest failure, such as increased predator densities. The effect of Neocalanus cristatus on daily nest survival was positive at both of our colonies, however, regardless of how frequently the colony was visited.

Seabirds may adapt to interannual variation in oceanographic conditions and prey availability by adjusting the timing of breeding (Bédard 1969b, Bertram et al. 2001, Abraham \& Sydeman 2004). Nesting chronology was closely synchronous for both auklet species; all monitored nests hatched and fledged over $10 \mathrm{~d}$ intervals in each year of the study. Median hatch dates were $8 \mathrm{~d}$ earlier for both species in 2002, however, and this was the year of highest reproductive success for both species at both colonies. In the western Aleutian Islands, years of earlier median hatching dates were also associated with higher reproductive success of crested auklets (Fraser et al. 1999). There is a decline in the transport of Anadyr water past St. Lawrence Island late in the chick-rearing season, reducing the prevalence on high-quality oceanic prey such as Neocalanus copepods (Springer et al. 1989). Food availability may, therefore, be the ultimate factor influencing the relationship between early egg laying 
and high reproductive success (Bertram et al. 2001, Hedd et al. 2002, Abraham \& Sydeman 2004). A change in oceanographic conditions may reduce prey availability beyond the auklet's adaptive response, however, creating a seasonal mismatch between the period of peak copepod availability and chick rearing (Bertram et al. 2001, Abraham \& Sydeman 2004). Changes in nesting chronology of least and crested auklets on St. Lawrence Island could be especially significant in light of the potential effects of global warming on sea ice and consequent effects on the productivity of the northern Bering Sea (Clement et al. 2004). Continued monitoring of auklet populations will provide the opportunity to tease apart the confounding effects of weather and food availability on the timing of breeding.

There is evidence of a trend toward decreased seaice cover and earlier sea ice retreat in the Bering Sea during the late 1990s compared to the 1970s (Hunt et al. 2002). Analysis of satellite imagery suggests a loss of Arctic ice extent averaging $3 \%$ per decade since 1978 (Gloersen \& Campbell 1991, Wyllie-Echevarria \& Ohtani 1999). These trends affect the timing and magnitude of zooplankton production in the northern Bering Sea by altering current dynamics and patterns of primary productivity. Concerns about global climate change and its effects on high-latitude ecosystems highlight the importance of monitoring auklet diet, nesting chronology, and reproductive success as indicators of change in the marine environment (Cairns 1987, Monaghan et al. 1996). Least auklets are known to forage up to $56 \mathrm{~km}$ from colonies on St. Lawrence Island in search of high-quality prey while provisioning chicks (Obst et al. 1995), providing an index to zooplankton availability within the Chirikov Basin. These data can be used to explore interannual variation in zooplankton availability, as well as the processes by which seabirds may compensate for this variation. Annual monitoring of productivity and diet of planktivorous auklets, in conjunction with studies of physical oceanography, can contribute to our understanding of how both natural and anthropogenic climate change affects the trophic structure of the northern Bering Sea ecosystem.

Acknowledgements. We thank the Savoonga and Gambell Native Corporations for permission to work on St. Lawrence Island, and especially C. Pelowook, M. Toolie, and H. Kingeekuk for their assistance in obtaining land-crossing permits. We also thank C. Akeya, L. DeMatteo, A. Gologergen, G. Kava, M. Miklahook, B. Milakovic, L. Sheffield, B. Waghiyi, and V. Zubakin for providing excellent assistance in the field. R. Alowa of Savoonga and J. Snyder of the USFWSMarine Mammals Management provided logistical help. We are grateful to K. Turco for identifying zooplankton and K. Coyle, Institute of Marine Science, University of Alaska, Fair- banks, for generously sharing his zooplankton data set. We thank R. Anthony, K. Dugger, and P. Flint for their advice on MARK analysis. D. Rizzolo was indispensable in the field and the office. We appreciate E. Holsberry, V. Powell, and S. Stephensen for their assistance. We appreciate the comments of 4 anonymous reviewers, which significantly improved an earlier draft of this manuscript. This study was funded by the US Fish and Wildlife Service, Region 7 - Migratory Bird Management office in Anchorage, Alaska; Oregon Sea Grant; and the USGS - Oregon Cooperative Fish and Wildlife Research Unit, which is jointly supported by the Oregon Department of Fish and Wildlife, Oregon State University, the US Geological Survey, and the Wildlife Management Institute.

\section{LITERATURE CITED}

Abraham CL, Sydeman WJ (2004) Ocean climate, euphausiids and auklet nesting: inter-annual trends and variation in phenology, diet and growth of a planktivorous seabird Ptychoramphus aleuticus. Mar Ecol Prog Ser 274:235-250

ACIA (2004) Impacts of a warming Arctic. Cambridge University Press, Cambridge. www.acia.uaf.edu/

Baier CT, Napp JM (2003) Climate-induced variability in Calanus marshallae populations. J Plankton Res 25:771-782

Bédard J (1969a) The nesting of the crested, least, and parakeet auklets on St. Lawrence Island, Alaska. Condor 71: $386-398$

Bédard J (1969b) Feeding of the least, crested, and parakeet auklets around St. Lawrence Island, Alaska. Can J Zool 47:1025-1050

Bertram DF, Jones IL, Cooch EG, Knechtel HA, Cooke F (2000) Survival rates of Cassin's and rhinoceros auklets at Triangle Island, British Columbia. Condor 102:155-162

Bertram DF, Mackas DL, McKinnell SM (2001) The season cycle revisited: interannual variation and ecosystem consequences. Prog Oceanogr 49:283-307

Bowman TE, Cohen AC, McGuiness MM (1982) Vertical distribution of Themisto gaudichaudi (Amphipoda: Hyperiidea) in deepwater dumpsite 106 off the Delaware Bay. Smithsonian Contributions to Zoology 351, Smithsonian Institution Press, Washington, DC

Burnham KP, Anderson DR (2002) Model selection and multimodel inference: a practical information-theoretic approach, 2nd edn. Springer, New York

Byrd GV, Day RH, Knudtson EP (1983) Patterns of colony attendance and censusing of auklets at Buldir Island, Alaska. Condor 85:274-280

Cairns DK (1987) Seabirds as monitors of marine food supplies. Biol Oceanogr 5:261-271

Clement JL, Cooper LW, Grebmeier JM (2004) Late winter water column and sea ice conditions in the northern Bering Sea. J Geophys Res 109:C03022

Cooch EG, White GC (2005) Program MARK: A gentle introduction, 4th edn. Available at: www.phidot.org/software/ mark/docs/book/Accessed August 2005

Coyle KO, Chavtur VG, Pinchuk AI (1996) Zooplankton of the Bering Sea: A review of Russian-language literature. In: Matheison O, Coyle KO (eds) Ecology of the Bering Sea: a review of Russian literature. Alaska Sea Grant College Program Report No. 96-01, University of Alaska, Fairbanks, AK, p 97-134

Dagg MJ, Clarke ME, Nishiyama T, Smith SL (1984) Production and standing stock of copepod nauplii, food items for larvae of the walleye pollock Theragra chalcogramma in the southeastern Bering Sea. Mar Ecol Prog Ser 19:7-16 
Dinsmore SJ, White GC, Knopf FL (2002) Advanced techniques for modeling avian nest survival. Ecology 83:3476-3488

Fraser G, Jones IL, Williams JC, Hunter FM, Scharf L, Byrd GV (1999) Breeding biology of crested auklets at Buldir and Kasatochi islands, Alaska. Auk 116:690-701

Fraser G, Jones IL, Hunter FM (2002) Male-female differences in parental care in monogamous crested auklets. Condor 104:413-423

Gloersen P, Cambell WJ (1991) Recent variations in arctic and antarctic sea ice covers. Nature 352:33-36

Haney JC (1991) Influence of pycnocline topography and water column structure on marine distributions of alcids (Aves: Alcidae) in Anadyr Strait, Northern Bering Sea, Alaska. Mar Biol 110:419-435

Hansell DA, Goering JJ, Walsh JJ, McRoy CP, Coachman LK, Whitledge TE (1989) Summer phytoplankton production and transport along the shelf break in the Bering Sea. Cont Shelf Res 9(12):1085-1104

Hare SR, Mantua NJ (2000) Empirical evidence for North Pacific regime shifts in 1977 and 1989. Prog Oceanogr 47: 103-146

Hatch SA, Hatch MA (1988) Colony attendance and population monitoring of Black-legged Kittiwakes on the Semidi Islands, Alaska. Condor 90:613-620

Hedd A, Ryder JL, Cowen LL, Bertram DF (2002) Inter-annual variation in the diet, provisioning and growth of Cassin's auklet at Triangle Island, British Columbia: responses to variation in ocean climate. Mar Ecol Prog Ser 229:221-232

Hunt GL, Harrison NM (1990) Foraging habitat and prey taken by least auklets at King Island, Alaska. Mar Ecol Prog Ser 65:141-150

Hunt GL, Harrison NM, Cooney RT (1990) The influence of hydrographic structure and prey abundance on foraging least auklets. Stud Avian Biol 14:7-22

Hunt GL, Russell RW, Coyle KO, Weingartner T (1998) Comparative foraging ecology of planktivorous auklets in relation to ocean physics and prey availability. Mar Ecol Prog Ser 167:241-259

Hunt GL, Stabeno P, Walters G, Sinclair E, Brodeur RD, Napp JM, Bond NA (2002) Climate change and control of the southeastern Bering Sea pelagic ecosystem. Deep-Sea Res Part II 49:5821-5853

Jones IL (1993a) Crested auklet (Aethia cristatella) In: Poole A, Gill F (eds) The birds of North America, No. 70. Academy of Natural Sciences of Philadelphia and the American Ornithologists' Union, Washington, DC

Jones IL (1993b) Least Auklet (Aethia pusilla) In: Poole A, Gill F (eds) The birds of North America, No. 69. Academy of Natural Sciences of Philadelphia and the American Ornithologists' Union, Washington, DC

Jones IL, Hunter FM, Robertson GJ (2002) Annual adult survival of least auklets (Aves, Alcidae) varies with largescale climatic conditions of the North Pacific Ocean. Oecologia 110:1-13

Lee RF (1975) Lipids of Arctic zooplankton. Comp Biochem Physiol B51:263-266

Macklin SA, Hunt GL, Overland JE (2002) Collaborative research on the pelagic ecosystem of the southeastern Bering Sea shelf. Deep-Sea Res Part II 49:5813-5819

Miller AJ, Schneider N (2000) Interdecadal climate regime dynamics in the North Pacific Ocean: theories, observations, and ecosystem impacts. Prog Oceanogr 47:355-379

Miller CB (1993) Neocalanus flemingeri, a new species of Calanidae (Copepoda: Calanoida) from the subarctic Pacific, May, 1984, with a comparative redescription of Neocalanus plumchrus (Marukawa). Prog Oceanogr 20: $223-273$
Miller CB, Frost BW, Batchelder HP, Clemons MJ, Conway RE (1984) Life histories of large, grazing copepods in a subarctic ocean gyre: Neocalanus plumchrus, Neocalanus cristatus, and Eucalanus bungii in the northeast Pacific. Prog Oceanogr 13:201-243

Monaghan P, Wright PJ, Baily MC, Uttley JD, P Walton, Burns MD (1996) The influence of changes in food abundance on diving and surface-feeding seabirds. Canadian Wildlife Service Occasional Papers 91:10-19

Niebauer HJ (1998) Variability in Bering Sea ice cover as affected by a regime shift in the North Pacific in the period 1947-1996. J Geophys Res C 103:27717-27737

Obst BS, Russell RW, Hunt GL, Eppley ZA, Harrison NM (1995) Foraging radii and energetics of least auklets (Aethia pusilla) breeding on 3 Bering Sea islands. Physiol Zool 68:647-672

Ocean ESIP (2001) PO.DAAC Ocean Earth Science Information Partner Tool. Retrieved November 24, 2004 from NASA, Jet Propulsion Laboratory Website: http://poet.jpl.nasa.gov/

Pavlov VK, Pavlov PV (1996) Oceanographic description of the Bering Sea. In: Mathieson O, Coyle KO (eds) Ecology of the Bering Sea: a review of Russian literature. Alaska Sea Grant College Program Report No. 96-01, University of Alaska, Fairbanks, AK, p 1-95

Piatt JF, Springer AM (2003) Advection, pelagic food webs and the biogeography of seabirds in Beringia. Mar Ornithol 31:141-154

Piatt JF, Hatch SA, Roberts BD, Lidster WW, Wells JL, Haney JC (1988) Populations, productivity, and feeding habitats of seabirds on St. Lawrence Island, Alaska. OCS Study MMS 88-0022 Final Report, Minerals Management Service, Anchorage, AK

Piatt JF, Roberts BD, Lidster WW, Wells JL, Hatch SA (1990) Effects of human disturbance on breeding least and crested auklets at St. Lawrence Island, Alaska. Auk 107:342-350

Ramsey FL, Schafer DW (2002) The statistical sleuth: a course in methods of data analysis, 2nd edn. Wadsworth, Belmont, CA

Roby DD, Brink KL (1986) Breeding biology of least auklets on the Pribilof Island, Alaska. Condor 88:336-346

Sealy SG (1975) Influence of snow on egg-laying in auklets. Auk 92:528-538

Seber GAF (1982) The estimation of animal abundance and related parameters. 2nd edn, Macmillan, New York

Springer AM, Roseneau DG (1985) Copepod-based food webs: auklets and oceanography in the Bering Sea. Mar Ecol Prog Ser 21:229-237

Springer AM, McRoy CP, Turco KR (1989) The paradox of pelagic food webs in the northern Bering Sea-II. Zooplankton communities. Cont Shelf Res 9:359-386

Stabeno PJ, Schumacher JD, Ohtani K (1999) The physical oceanography of the Bering Sea. In: Loughlin TR, Ohtani $\mathrm{K}$ (eds) Dynamics of the Bering Sea: a summary of physical, chemical, and biological characteristics, and a synopsis of research on the Bering Sea. North Pacific Marine Science Organization (PICES), University of Alaska Sea Grant, Fairbanks, AK

Stephensen SW, Irons DB (2003) Comparison of colonial breeding seabirds in the eastern Bering Sea and Gulf of Alaska. Mar Ornithol 31:167-173

Stephensen SW, Pungowiyi C, Mendenhall VM (1998) A seabird survey of St. Lawrence Island, Alaska 1996-1997. US Fish and Wildlife Services Report, Migratory Bird Management (MBM), Anchorage, AK

Swanson GA, Krapu GL, Bartonek JC, Serie JR, Johnson DH (1974) Advantages in mathematically weighting waterfowl food habits data. J Wildl Manage 38:302-307 
Traylor JJ, Alisaukas RT, Kehoe FP (2004) Nesting ecology of white-winged scoters (Melanitta fusca deglandi) at Redberry Lake, Saskatchewan. Auk 121:950-962

Williams JC, Scharf L, Byrd GV (2000) Ecological monitoring methods of the Aleutian Islands Unit, Alaska Maritime National Wildlife Refuge. US Fish and Wildlife Services Report AMNWR 00/01 Adak, AK

Woodgate RA, Aagaard K, Weingartner TJ (2005) Monthly temperature, salinity, and transport variability of the

Editorial responsibility: Otto Kinne (Editor-in-Chief), Oldendorf/Luhe, Germany
Bering Strait through flow. Geophys Res Lett 32, L04601; doi:10.1029/2004GL021880

Wyllie-Echevarria T, Ohtani K (1999) Seasonal sea ice variability and the Bering Sea ecosystem. In: Loughlin TR, Ohtani K (eds) Dynamics of the Bering Sea: a summary of physical, chemical, and biological characteristics, and a synopsis of research on the Bering Sea. North Pacific Marine Science Organization (PICES), University of Alaska Sea Grant, Fairbanks, AK

Submitted: March 4, 2005; Accepted: September 2, 2005 Proofs received from author(s): January 28, 2006 